\title{
ODOURLESS REMOVAL OF SKUNKS
}

\author{
by P. Fraser, Wolseley
}

Frequently that beautiful little animal, the skunk, gets into a place from which it has to be removed. The common practice is to shoot it but this results in the discharge of offensive fluid. An Indian once told me that if a skunk was snared and gently choked it would not discharge. One fall I had an opportunity to try this and successfully disposed of seven skunks without leaving any odour.

The skunks, evidently a family including the mother, got into a small outhouse where I kept meat and butter and other things. They came in through a hole under the bottom log of this little building which had only an earthen floor. I got the skunks out, one every few days, by using a stick about seven feet long and making a little snare of cord on the end of it.
I would reach out and snare a skunk." It would try unsuccessfully to push the snare off. In a very few minutes it would be unconscious and could be lifted off the ground and removed. Dead skunks may be buried and will not leave any odour. This method does not work well outdoors for the skunk will keep its nose down among the grass and weeds.

The Indians where I lived used to say that skunk was very good meat. In the fall of 1891 when skunk skins sold for fifty cents each I used to get an Indian 10 do the skinning. He got the meat and I got the skin.

In the early summer cutworms are a delicacy for skunks. They eat thousands of them. During the fall a large part of the diet of skunks may be frogs and salamanders.

\section{LETTERS}

\section{IN MEMORIAM: HERBERT PAUL WALTER}

On June 11, 1961. Herbert Walter of Wiseton was drowned at Clearwater Lake. His untimely death at the age of 21 is mourned by his parents, Mr. and Mrs. Albert Walter of Dunleath, three brothers and two sisters and his grandmothers, Mrs. Mary Walter and Mrs. Emma Leipert, both of Yorkton.

Herbert was a long time reader of the Blue Jay and when he lived in Yorkton he knew Dr. Stuart Houston and Cliff Shaw. When he left home to make a living for himself he kept up his interest in nature and soon bought himself a movie camera. Although he was fond of scenery of all kinds some of his favorite reels are about squirrels, foxes and birds.

Herbert had a sincere but quiet interest in all the outdoors. He could spend hours watching or listening to the birds and mammals. All members of the Saskatchewan Natural History Society who knew him will mourn his untimely death.

\section{MORE LONG ARTICLES}

It is only after being disassociated from actual participation in the activities of the Society through being absent from the summer and annual meetings that I fully realize what an excellent job the Blue Jay does in keeping isolated members informed of new developments and current problems confronting our field of interest.

Regarding the suggestion in the last issue that the number of long articles should be reduced in favour of letters and brief notes, I agree that although the short pieces may be of more interest to the casual reader, and give more members an opportunity to see their names mentioned, it is still the scientific report prepared by the 'expert' that provides the 'meat' and will be of lasting value. Although I'd like to see as many brief notes as possible let's not have them at the expense of the accurate, detailed reports. - William Anaka, Spirit Lake. 